\title{
The adaptation of creativity in museum sector: a case study of Malacca Maritime Museum, Malaysia
}

\begin{abstract}
Museum is a cultural institution which plays an important role in cultural tourism activities. Today, the role of traditional museums has shifted to become multipurpose in order to offer tangible and intangible products and services to their visitors. The tourism industry in Malaysia is heavily depending on their rich multiethnic and religion culture since the 50's. However, the progress of the museums in Malaysia is going at a slow phase although cultural tourism growth in the country is soaring. Any changes involving the museum sector in Malaysia went through a complicated process because it had to go through several stages and time consuming. The museum sector in Malaysia is lacking of creative management and administration style. Malaysia museum sector is left far behind almost 30 years compared to other developed countries. Notwithstanding, for the past ten years more Malaysian museums are shifting their roles to become modern museums by adapting creative ideas and technology. This study applied case study method on Malacca Maritime Museum. This is a traditional museum which comes up with new and fresh ideas by combining traditional, creativity and ICT elements to become modern museum. Hence, this museum remains competitive with other tourism attractions in Malaysia and the region.
\end{abstract}

Keyword: Creativity; Cultural tourism; Modern museum; Museum; Traditional museum 